\title{
HUBUNGAN PEMBERIAN ASI EKSKLUSIF DENGAN KEJADIAN KARIES GIGI PADA ANAK USIA 2-4 TAHUN DI KELOMPOK BERMAIN DESA GADING WATU GRESIK
}

\author{
Amaliya Firdaus', Retno Setyo Iswati²
}

\author{
1.Mahasiswa Prodi DIII Kebidanan Universitas PGRI Adi Buana Surabaya \\ 2. Tenaga pengajar Prodi DIII Kebidanan Universitas PGRI Adi Buana Surabaya
}

\begin{abstract}
ABSTRAK
ASI Eksklusif mempunyai banyak manfaat bagi kesehatan ibu dan anak. Salah satu manfaat ASI Eksklusif adalah dapat mencegah resiko gigi berlubang atau karies gigi (Khamzah, 2012: 180). Penelitian ini bertujuan mengidentifikasi hubungan pemberian ASI Eksklusif dengan kejadian karies gigi pada anak usia 2-4 tahun. Penelitian ini menggunakan metode analitik korelasi dengan desain penelitian case-control yang dilakukan pada bulan Maret sampai Mei 2013 di Kelompok Bermain Gading dengan populasi seluruh ibu dan anak usia 2-4 tahun yang berjumlah 30 responden dan sampel yang digunakan adalah sampel jenuh/sensus, menggunakan data primer dengan instrument berupa kuesioner dan checklist dengan metode analisis Chi-Square .Berdasarkan hasil penelitian didapatkan dari 30 responden sebagian besar responden yang diberikan ASI eksklusif sebanyak 83,33\% tidak mengalami karies gigi dan sebagian kecil sejumlah $16,67 \%$ mengalami karies gigi, sedangkan responden yang tidak diberikan ASI eksklusif sebanyak $95,83 \%$ mengalami karies gigi dan sebagian kecil sejumlah $4,17 \%$ tidak mengalami karies gigi . Simpulan dari penelitian ini adalah sebagian besar anak tidak diberikan ASI eksklusif dan banyak anak yang mengalami karies gigi, dari hasil uji analisis Chi-Square ada hubungan pemberian ASI eksklusif dengan kejadian karies gigi pada anak usia 2-4 tahun. Saran yang dapat diberikan penyuluhan tantang pemberian ASI Eksklusif ditingkatkan di semua tatanan pelayanan kesehatan.
\end{abstract}

Kata Kunci: ASI Eksklusif, Karies Gigi, Anak Usia 2-4 Tahun

\section{PENDAHULUAN}

Rekomendasi pemberian ASI eksklusif selama 6 bulan pertama didasarkan pada bukti ilmiah manfaat ASI bagi daya tahan hidup bayi, pertumbuhan dan perkembangannya. ASI memberi semua nutrisi yang dibutuhkan bayi selama 6 bulan pertama hidupnya dan pemberian ASI eksklusif mengurangi tingkat kematian bayi (http://tantursyah.blogspot.com yang diakses pada tanggal 4 Maret 2013 pukul 20.52 WIB). Selain itu diketahui bahwa kandungan selenium yang banyak dalam ASI mampu melindungi bayi terhadap timbulnya karies gigi. Karies gigi bayi yang terdapat pada susu formula jauh lebih tinggi dibanding yang terdapat pada ASI, jadi bisa dikatakan bahwa pemberian ASI secara eksklusif minimal sampai usia 6 bulan dapat mencegah risiko karies gigi dan gigi berlubang (Khamzah, 2012: 187).

Karies gigi adalah penyakit infeksi yang merusak struktur gigi dan menyebabkan gigi berlubang. Gigi berlubang mempunyai akibat yang fatal jika tidak diobati atau ditambal, karena akan mengakibatkan infeksi gigi menjadi meluas dan menjadi saranamasuknya kuman penyakit yang dapat menyebabkan infeksi pada paru-paru, jantung dan otak yang dapat menyebabkan kematian, selain itu bahaya penyakit gigi pada anak-anak bisa berlanjut hingga dewasadan bisa memicu penyakit lain, seperti stroke dan diabetes(http://batam.tribunnews.com yang diakses pada tanggal 24 Februari 2013 pukul 13.46 WIB).

National Institution of Health di Amerika Serikat melaporkan pada tahun 2000 kasus karies gigi terutama pada anak-anak usia 5-17 tahun kasusnya lebih banyak lima kali dibandingkan asma dan tujuh kali dari demam akibat alergi. Saat ini gigi berlubang telah menjadi penyakit yang tersebar di seluruh dunia. Penelitian tim Riset Kesehatan Dasar Depkes 2007 bahwa 71\% masyarakat Indonesia mengalami masalah gigi berlubang.

Hasil survey pendahuluan yang peneliti lakukan pada bulan Februari 2013 di Kelompok Bermain Gading menemukan bahwa dari 30 anak usia 2-4 tahun, sebanyak 24 anak yang mengalami karies. Berdasarkan hal tersebut peneliti merasa tertarik untuk meneliti Hubungan Pemberian ASI Eksklusif dengan Kejadian Karies Gigi pada Anak Usia 2-4 Tahun 
Di Kelompok Bermain Gading Desa Gadingwatu Menganti Gresik.

Rumusan masalah pada penelitian ini adalah adakah hubungan pemberian ASI Eksklusif dengan kejadian karies gigi pada Anak Usia 2-4 Tahun Di Kelompok Bermain Gading Desa Gadingwatu Menganti Gresik .

Tujuan umum penelitian ini adalah untuk mengetahui apakah ada hubungan pemberian ASI Eksklusif dengan kejadian karies gigi pada anak usia 2-4 tahun di kelompok bermain desa Gadingwatu Menganti Gresik.

Tujuan khususnya adalah

1) Mengidentifikasi pemberian ASI Eksklusif pada anak usia 2-4 tahun.

2) Mengidentifikasi kejadian karies gigi pada anak usia 2-4 tahun.

3) Menganalisis hubungan pemberian ASI eksklusif dengan kejadian karies gigi pada anak usia 2-4 tahun.

\section{BAHAN DAN METODE}

Desain penelitian yang digunakan adalah analitik korelasi dengan menggunakan pendekatan secara case-control. Pada penelitian ini populasinya adalah seluruh ibu dan anak usia 2-4 tahun yang berada di Kelompok Bermain Gading Desa Gadingwatu Kecamatan Menganti Kabupaten Gresik yang berjumlah 30 responden. Sampel yang digunakan adalah sampel jenuh. Variabel dalam penelitian ini adalah dua variabel yaitu variabel bebas dan variabel terikat. Variabel bebas adalahpemberian ASI eksklusif. dan variabel terikat adalah kejadian karies pada anak.

\section{Pemberian ASI Eksklusif adalah haRemberian} memberikan ASI saja tanpa tambahan apapunASI kecuali vitamin, mineral dan sirup obat selaetksklusif 6 bulan yang didapatkan peneliti dari kuesion ídak AS Kejadian karies gigi adalah kerusakan yạgak AS terjadi pada gigi anak yang didapatkan penettt ASI dari checklist. Data yang digunakan adalah $h_{\text {ASklusi }}$ data primer dengan menggunakan instrumejumlah kuesioner dan checklist. Waktu penelitianumlah adalah bulan Maret - Mei 2013 dan tempat penelitian adalah di Kelompok Bermain Gading Desa Gadingwatu Kecamatan Menganti Kabupaten Gresik.

\section{HASIL DAN PEMBAHASAN \\ Data pemberian ASI secara eksklusif \\ Tabel 1.}

Distribusi frekuensi pemberian ASI secara Eksklusif

\begin{tabular}{lcc}
\hline $\begin{array}{c}\text { Pemberian ASI } \\
\text { Eksklusif }\end{array}$ & Jumlah & $\begin{array}{c}\text { Persentase } \\
(\%)\end{array}$ \\
\hline ASI Eksklusif & 6 & 20 \\
Tidak ASI Eksklusif & 24 & 80 \\
\hline Jumlah & $\mathbf{3 0}$ & $\mathbf{1 0 0}$ \\
\hline
\end{tabular}

Sumber: Data Primer, 2013

Berdasarkan tabel 1 menunjukkan bahwa dari 30 responden, sebanyak 24 responden (ibu) $(80 \%)$ tidak memberikan ASI secara eksklusif

\section{Data kejadian karies gigi pada anak usia 2-4 tahun}

Tabel 2.

Distribusi responden berdasarkan kejadian karies gigi

\begin{tabular}{lcc}
\hline $\begin{array}{c}\text { Kejadian Karies } \\
\text { Gigi }\end{array}$ & Jumlah & $\begin{array}{c}\text { Persentase } \\
(\%)\end{array}$ \\
\hline Tidak Karies Gigi & 6 & 20 \\
Karies Gigi & 24 & 80 \\
\hline Jumlah & $\mathbf{3 0}$ & $\mathbf{1 0 0}$ \\
\hline
\end{tabular}

Sumber: Data Primer, 2013

Berdasarkan tabel 2 menunjukkan bahwa dari 30 responden, sebanyak 24 responden (anak) $(80 \%)$ mengalami karies gigi

\section{Analisis Data}

Hubungan pemberian ASI secara eksklusif dengan kejadian karies gigi pada anak usia 2-4 tahun

Tabel 3.

Tabel silang hubungan pemberian ASI secara eksklusif dengan kejadian karies gigi pada anak usia 2-4 tahun

\begin{tabular}{|c|c|c|c|c|c|}
\hline \multicolumn{6}{|c|}{$\begin{array}{l}\text { Kejadian karies pada anak usia 2-4 } \\
\text { tahun }\end{array}$} \\
\hline \multicolumn{2}{|c|}{ Karies } & \multicolumn{2}{|c|}{ Tidak Karies } & \multicolumn{2}{|c|}{ Jumlah } \\
\hline $\mathbf{N}$ & $\%$ & $\mathbf{N}$ & $\%$ & $\mathbf{N}$ & $\%$ \\
\hline 23 & 95,83 & 1 & 4,17 & 24 & 100 \\
\hline 1 & 16,67 & 5 & 83,33 & 6 & 100 \\
\hline 24 & 80 & 6 & 20 & 30 & 100 \\
\hline
\end{tabular}

Sumber: Data Primer, 2013

Tabel 3. Menjelaskan bahwa sebagian besar responden yang diberikan ASI eksklusif sebanyak 83,33\% (5 responden) tidak mengalami karies gigi dan sebagian kecil sejumlah $16,67 \%$ (1 responden) mengalami karies gigi, sedangkan responden yang tidak diberikan ASI eksklusif sebanyak 95,83\% (23 responden) mengalami karies gigi dan 
sebagian kecil sejumlah 4,17\% (1 responden) tidak mengalami karies gigi .

Berdasarkan uji Chi-Square dengan tingkat kemaknaan atau toleransi kesalahan $\alpha$ $0,05(5 \%)$ dan tingkat kepercayaan 95\% didapatkan $\chi^{2}$ hitung $=18,8>\chi^{2}$ tabel $=3,841$ yang artinya ada hubungan pemberian ASI secara eksklusif dengan kejadian karies gigi pada anak usia 2-4 tahun di kelompok bermain gading desa Gadingwatu Menganti Gresik.

\section{Pembahasan}

\section{Pemberian ASI secara eksklusif}

Hasil penelitian pada tabel 1 menunjukkan bahwa sebagian besar ibu-ibu tidak memberikan ASI secara eksklusif, dari 30 responden yang diberikan ASI eksklusif berjumlah $6(20 \%)$ responden dan yang 24 $(80 \%)$ responden tidak diberikan ASI eksklusif.

Penurunan pemberian dan penggunaan

ASI di pedesaan terjadi karena adanya kecenderungan dari masyarakat untuk meniru sesuatu yang dianggapnya modern yang datang dari negara yang telah maju atau yang datang dari kota besar. Berdasarkan survey demografi dan kesehatan Indonesia pada tahun 1997 dan 2003, diketahui bahwa angka pemberian ASI eksklusif turun dari 49\% menjadi 39\%, sedangkan penggunaan susu formula meningkat tiga kali lipat. Informasi tersebut disampaikan oleh Ketua Badan Kerja Peningkatan Penggunaan Air Susu lbu (BKPPASI), dr. Dien Santoso Besar, Sp. A. Selain itu, survei yang dilakukan oleh Hellen Keller International pada tahun 2002 di Indonesia, diketahui bahwa rata-rata bayi Indonesia hanya mendapatkan ASI eksklusif selama 1,7 bulan. Padahal, kajian WHO yang di tuangkan dalam Kepmen No. 450 tahun 2004 menganjurkan agar bayi diberi ASI eksklusif selama 6 bulan (Prasetyono, 2012:23).

\section{Kejadian karies gigi}

Tabel 2 menunjukkan bahwa sebagian besar anak mengalami karies gigi yang berjumlah 24 (80\%) responden dan sebagian kecil sejumlah 6 (20\%) responden tidak mengalami karies gigi.

Sebagian besar responden yang mengalami karies memang tidak diberikan ASI secara eksklusif, dari 6 responden yang tidak mengalami karies hanya 1 responden yang tidak diberikan ASI eksklusif dan 5 responden diberikan ASI eksklusif. Pemberian ASI memang sangat erat hubungannya dengan kejadian karies gigi, namun ada banyak faktor lainnya yang menyebabkan terjadinya karies pada gigi anak. Selain faktor ASI eksklusif, pada kasus karies ini memang banyak penyebabnya, dari hasil jawaban kuesioner yang telah didapatkan bahwa anak yang mengalami karies gigi cenderung menyukai makanan yang manis-manis dan lengket seperti permen, kue coklat, dan lain sebagainya serta kurangnya pengawasan dari orang tua khususnya ibu untuk menjaga kebersihan gigi dengan cara rajin menggosok gigi dan pergi periksa ke dokter gigi.

\section{Hubungan pemberian ASI secara eksklusif dengan kejadian karies gigi pada anak usia 2-4 tahun}

Hasil penelitian menunjukkan bahwa sebagian besar responden yang diberikan ASI eksklusif sebanyak 83,33\% (5 responden) tidak mengalami karies gigi dan sebagian kecil sejumlah $16,67 \%$ (1 responden) mengalami karies gigi, sedangkan responden yang tidak diberikan ASI eksklusif sebanyak 95,84\% (23 responden) mengalami karies gigi dan sebagian kecil sejumlah 4,16\% (1 responden) tidak mengalami karies gigi . Berdasarkan uji Chi-Square didapatkan $x^{2}$ hitung $=18,8>x^{2}$ tabel $=3,841$ yang artinya ada Hubungan Pemberian ASI Secara Eksklusif Dengan Kejadian Karies Gigi Pada Anak Usia 2-4 Tahun Di Kelompok Bermain Gading Desa Gadingwatu Menganti Gresik.

Gigi berlubang disebabkan oleh email gigi yang keropos. Masalah gigi berlubang ini termasuk persoalan yang serius, sebab peran gigi sangat penting dalam mengunyah makanan untuk pertumbuhan dan perkembangan anak. Kasus karies gigi sebenarnya dapat dicegah secara dini dengan menjaga gigi sejak awal pembentukan gigi susu, yakni pada usia 6-8 minggu dalam kandungan, makanan yang di konsumsi oleh ibu itu cukup gizinya. Kekurangan mineral, vitamin, apalagi kekurangan gizi, secara umum akan membuat penjagaan gigi anak (baik gigi susu maupun gigi tetap nantinya) menjadi lebih sulit. Anak-anak dengan gigi yang sehat maka harus dimulai sejak dalam kandungan. Selain itu, harus dilanjutkan dengan pemberian ASI secara Eksklusif setelah bayi terlahir. Sebab, ASI Eksklusif dapat mencegah resiko gigi berlubang atau karies gigi (khamzah, 2012: 180).

Berdasarkan teori yang telah dijelaskan di atas dengan hasil penelitian yang telah dilakukan didapatkan kesamaan yaitu anak 
yang diberikan ASI eksklusif cenderung tidak mengalami karies gigi, sedangkan anak yang tidak diberikan ASI eksklusif cenderung mengalami karies gigi. Sesuai dengan asil penelitian menunjukkan bahwa sebagian besar responden yang diberikan ASI eksklusif sebanyak 83,33\% (5 responden) tidak mengalami karies gigi dan responden yang tidak diberikan ASI eksklusif sebanyak 95,84\% (23 responden) mengalami karies gigi.

\section{Simpulan dan Saran}

Berdasarkan tujuan penelitian yaitu mengetahui hubungan pemberian ASI eksklusif dengan kejadian karies gigi pada anak usia 2-4 tahun di kelompok bermain gading desa gadingwatu menganti Gresik maka kesimpulan yang didapat adalah sebagai berikut :

1) Sebagian besar anak usia 2-4 tahun yang ada di Kelompok Bermain Gading tidakmendapatkan ASI eksklusif.

2) Sebagian besar anak usia 2-4 tahun yang ada di Kelompok Bermain Gading mengalami kejadian karies gigi.

3) Ada hubungan antara pemberian ASI secara eksklusif dengan kejadian karies gigi pada anak usia 2-4 tahun di kelompok bermain Gading Desa Gadingwatu Menganti Gresik.

Berdasarkan hasil penelitian maka disarankan sebagai berikut :

1) Bagi Instansi yang terkait (kelompok bermain), sebaiknya anak diberikan pendidikan dini tentang kesehatan dan perawatan gigi agar anak mengerti tentang perlunya menjaga dan merawat gigi susunya dengan benar, sehingga dapat mengurangi kejadian karies gigi anak.

2) Bagi masyarakat, hendaknyameningkatkan kesadaran masyarakat khususnya para ibu tentang pentingnya pemberian ASI eksklusif untuk menjaga kesehatan gigi anak/gigi susu dalam mencegah terjadinya karies gigi sebagai langkah awal pembentukan gigi dewasa serta melindungi dari bahaya karies pada gigi khususnya pada anak.

\section{DAFTAR PUSTAKA}

Andlaw, R. J dan W.P. Rock. 1992. Perawatan Gigi Anak. Jakarta: Widya Medika.

Azwar, Saifuddin. 2012. Reliabilitas dan Validitas. Yogyakarta : Pustaka Pelajar.
Departemen Kesehatan Republik Indonesia. 2009. Buku Kesehatan Ibu Dan Anak. Jakarta: Departemen Kesehatan dan JICA (Japan International Cooperation Agency).

Khamzah, Siti Nur. 2012. Segudang Keajaiban ASI yang Harus Anda Ketahui. Jogyakarta : FlashBooks.

Margareta, Shinta. 2012. 101 Tips dan Terapi Alami Agar Gigi Putih dan Sehat. Yogyakarta: Pustaka Cerdas.

Nurdiansyah, Nia. 2011. Buku Pintar Ibu dan Bayi. Jakarta: Bukune.

Saryono, Ari Setiawan. 2011. Metodologi Penelitian Kebidanan DIII, DIV, S1 dan S2. Yogyakarta : Nuha Medika.

Srigupta, Aziz Ahmad. 2004. Perawatan Gigi dan Mulut. Jakarta: Prestasi Pustaka.

Suntoyo, Danang. 2012. Biostatistik untuk kebidanan. Yogyakarta : Nuha Medika.

Soetjiningsih. 2012. Seri Gizi Klinik ASI Petunjuk untuk Petugas Kesehatan. Jakarta: EGC.

Tribun

Batam.

2012.http://batam.tribunnews.com yang diakses pada tanggal 24 Februari 2013 pukul 13.46 WIB.

Yahya,

Harun. 2013. http://tantursyah.blogspot.com yang diakses pada tanggal 4 Maret 2013 pukul 20.52 WIB. 